\title{
Going beyond address forms
}

\section{Variation and style in the use of the second-person pronouns tú and usted}

\author{
María José Serrano \\ Universidad de La Laguna, Tenerife
}

The cognitive properties of morphosyntactic choices are at the base of any usage, patterns and tendencies they could possibly reveal; thus, by means of the cognitive properties of salience and informativeness, variation in second-person tú and usted must be considered as inherently meaningful, implying that each form conveys a different meaning that is used to pursue concrete communicative goals in discursive interaction. A qualitative and quantitative analysis of tú and usted and their syntactic variants (preverbal, postverbal and omitted) reveals that these forms are unevenly distributed across different textual genres and socioprofessional affiliations of speakers. It may be concluded that $t \dot{u}$ and usted contribute toward shaping the different communicative styles on the basis of the cognitive dimensions of objectivity and subjectivity, respectively. Considering these pronouns as meaningful choices by themselves, this study attempts to go beyond the traditional approach that treats them as terms of address, delving into the discursive and cognitive traits which underlie such a variation.

Keywords: address forms, sociolinguistics, style, tú, usted, variation

\section{Variation in the use of second-person singular pronouns tú and usted}

As different ways to index interlocutors during discourse, the Spanish second-person singular pronouns tú and usted are a case of linguistic variation traditionally approached as terms of address with opposite 'informal/formal' or 'impolite/polite' meanings, respectively on the basis of some underlying notion of social distance.

However, some studies about these pronouns have tried to overcome the assumption that the most important function they achieve is their alleged correlation with the power and solidarity axis by the way of the relationships established 
among speakers, or even with certain psychosocial features such as age, socioprofessional status or sex/gender (e.g. Ardehali 1990; Kendall 1981; Martiny 1996; Spencer-Oatey 1996). Tú and usted are possibly powerful resources for shaping social identities and face (Duszak 2002; Mühlhäusler \& Jarré 1990; Stewart 2003), which facilitate the management of the speaker and addressee images in a variable way (Serrano 2001:265).

Notwithstanding, speakers' address behaviours are not only conditioned by elements such as social factors but they are also dependent on other linguistic functions and communicative goals (Martiny 1996: 772). The interpretation of terms of address is highly dependent on the particular contexts in which interaction takes place (Watts, Ide \& Ehlich 1992) and would give rise to diverse or even contradictory solutions (Blas Arroyo 2005:312).

The choice of any pronoun during a discourse constitutes a membership categorization (cf. Sacks 1972; Schegloff 2007) defined as "the way in which conversational interactants use social classifications to describe and provide an abbreviated form of reference for the social actors they invoke, as a kind of reification of sub-conscious observations made in their day-to-day activities" (Stirling \& Manderson 2011: 1583). Hence, it can be easily inferred that rather than observing whether the speakers select either tú or usted according to the social status of the interlocutor, to consider a choice such as the one conditioned by the context or the communicative situation where each one seems more appropriate to be used, is more important (Hummel 2010: 110, 114-115).

Relevant as this topic may be in (socio)linguistics, it has been approached from diverse theoretical angles, e.g. the philological model of Lapesa, the traditional applications of solidarity vs. power dimensions (Brown \& Gilman 1960), correlational stratifications considering tú/usted as contextual alternatives, and the most modern sociopragmatic and politeness theories (v. Medina Morales 2010:25-44). Address terms may also be approached following the indexical orders proposed by Silverstein (2003: 193-194) that examine the contexts where the usage of a concrete form should be more or less appropriate or normative. First-order indexicalities are the observable patterns of use that can become encoded for more significant social meaningfulness (second-order indexicals) and even part of the metapragmatics of a culture (third-order indexicals). Williams and van Compernolle studied the use of the French second-person $t u$ and vous-singular in electronic environments where social indexicality is usually reduced concluding that even though there is a general preference for the use of $t u$ the rate of vous singular does not exhibit an important decrease (2009:378). From that perspective, these forms have been also studied as address strategies in online personal ads (van Compernolle 2008). Moreover, analyses of the variation between $t u$ and $u s t e d$ have taken advantage of the consideration of these pronouns as iconic or semiotic stylistic features used 
by speakers to achieve concrete communicative goals, such as those performed in some advertising media texts with persuasive purposes (cf. Aijón Oliva 2009). Nonetheless, there is still a broader explanation that not only considers the different indexing possibilities of the second-person singular pronouns but also envisages differences at the cognitive level.

Although both tú and usted are interpreted as second-person singular pronouns, only the former is actually a real second person; usted resulted from the evolution of the noun phrase vuestra merced ('your mercy'), which was used in classic Spanish as a polite form of address with third-person grammatical agreement ('Usted tiene'/'You frml. have').

It can thus be hypothesized that rather than a simple case of formal variation, the second-person singular pronouns tú and usted constitute a matter of communicative choice with repercussions not only on the management of the image of the speaker or interlocutor but also on the meaning that is intended to be communicated. The inherent semantic nature of grammar entails that any change in a grammatical form involves a difference in its meaning (Aijón Oliva \& Serrano 2013:28-29; García 2009; Langacker 2009; Goldberg 1995:67), and such an assumption would imply that syntactic constructions with either tú or usted will convey different ways of indexing the second person during discourse, the latter implying an increase in the iconic distance from the interlocutor which has the power to create meanings at a wide array of levels (Serrano 2006:69-70). This is consistent with the traditional considerations of $u$ sted as an address form marked by a formal, polite or distancing function, but allows for the systematization of such a perception from a cognitive viewpoint and at the same time providing a more realistic understanding of its variation with $t$ ú, far from simple and descriptive social evaluations.

It is necessary to integrate the sociosemiotic level of address-form choices with their discursive-cognitive features to explain the notional grounds of linguistic variation. In this line, given that $t \dot{u}-u s t e d$ variation is inherently meaningful, the present study departs from the idea that they may be used to pursue concrete communicative goals that contribute to shaping communicative styles on the basis of the cognitive dimensions of objectivity and subjectivity. Previous studies have proved that the variation of pronominal subjects contributes to developing communicative styles in discursive interaction (cf. Aijón Oliva \& Serrano 2013; Serrano 2011: 159-173).

The research questions to be answered in this study are as follows:

a. Do the cognitive salience of the pronouns tú and usted give rise to different meanings in discursive interaction?

b. Do the informativeness of the pronouns tú and usted give rise to different meanings in discursive interaction? 
c. Is there any demonstrable patterned connection between the choice of $t u$ and usted and their variants across different textual genres and the various socioprofessional affiliations of speakers?

d. Is this variation contributing to creating different communicative styles?

The first step in this investigation will be to explore the cognitive properties (salience and informativeness) of the morphosyntactic variants of the second-person pronouns tú and usted (Section 2). The methodology employed will be described in Section 3. In the subsequent sections $(4,5$ and 6$)$ the distribution and frequencies of these pronouns as absolute and relative variables in different texts and socioprofessional affiliations of speakers will allow to determine the nature of the communicative style created through them.

\section{Variation and meaning of pronominal subjects}

\subsection{Salience and informativeness during discourse}

To adequately understand the formal variation of pronominal subjects in Spanish, it is necessary to put forward that any linguistic choice generates a meaning in conjunction with many other semantic and formal features.

Identifying the referent when a subject is omitted is possible thanks to verbal desinences, which act as disambiguating and deictic elements. Those of the first- and second-person pronouns are more prone to be recognized than the third-person just because they refer to the direct participants in interaction. The referent of an omitted subject is considered to be salient, accessible or activated in the context (Ariel 2001; Gundel \& Fretheim 2009; Gundel, Hedberg \& Zacharski 1993), and it presents known information that is normally placed at the beginning of the clause (Prince 1981:230). Salience is a cognitive conceptualization based on the perceptual relevance that an entity achieves during discourse by means of language (Croft \& Cruse 2004:46-50) and it is grounded on the cognitive process of attention, understood as the activation of structures in the mind across communicative acts (Langacker 2009: 112). A great number of studies have confirmed the relationship between known information, accessibility and salience (Giora 2003).

The following excerpt shows that the continuity of the referent of the omitted subject - formulated previously (Adán) - is maintained through the verbal desinences and verbal clitics; therefore, it is not necessary to reformulate it.

(1) La foto que tenemos de Adán es con la chaqueta enrollada debajo del brazo||tuve la suerte de hacerle oposición y eso significa oposiciónlen esos debates que teníamos $\varnothing$ se cogía sus calenturaslpor eso yo creo que lo vamos a echar de menos porque $\varnothing$ era todo ideas

(CCEC Med12 <ElEnv1010>) 
'The picture we have of Adán is one showing his jacket wrapped under his arm. I was lucky to be an opponent of his, and that means opposition indeed. In those debates we used to have [he] would get really angry. That's why I think we are going to miss him a lot - [he] was full of ideas'.

On the other hand, an expressed subject conveys textual informativeness by itself and will imply a higher degree of unexpectability and cognitive processing of the referent of the subject, providing contrastive or new information during the utterance (Lambrecht 1994:273). This would justify the usual perception of informative elements to be construed with some type of creativity (Beaugrande \& Dressler 1997: 76). Informativeness denotes a cognitive stressing of linguistic elements that makes the more informative element become pragmatically focused or gives it an acquired pragmatic weight (Davidson 1996:551). ${ }^{1}$

(2) A: Tú piensa en el que lo vaya a leer/tú escríbelo y ya luego lo corregimos\

B: No sé por qué no me gusta la Navidad।

A: Tú escribe 'La Navidad'

$($ CCEC Conv $<$ ElEn08 $>)$

'A: You think about the person who's going to read it. You write it and then we'll correct it.

B: Well, I don't know why I don't like Christmas.

A: You just write 'Christmas'.

Salience and informativeness are gradual and inversely proportional cognitive dimensions. This means that those more activated linguistic elements in a discourse will not be informative, whereas those newly introduced will possess higher informativeness and lesser salience (Aijón Oliva \& Serrano 2013:32-34).

These notions may also be applied to the preverbal or postverbal placement of the subject. Prototypical declarative clauses in Spanish follow the unmarked subject - verb - object (SVO) order (Fried 2009) and information progresses from subject to object, thus the subject is considered to be more salient and the object more informative. For the same reason, it can be stated that a postverbal subject acquires notional features of the object in this syntactic position, its salience is reduced, the informativeness will increase and the referent of the pronoun will be focused (See 4.1.). The clause 'dibujarían ustedes' ('you (postv.) would draw') illustrates this in the following example.

1. Pragmatic weight is a "theoretical label which subsumes the notion of emphasis which may explain how to disambiguate epistemic parentheticals, trigger speech acts' readings of certain verbs and increase their "stake" in whatever they are saying" (Davidson 1996:551). Utterances with expressed subjects are considered as weightier and more invested with emotion than other types of utterances (1996:555-556). 
(3) Antes de decirles adiós y agradecerles que hayan compartido con nosotros su tiempo sintonizando/ les pediríamos que nos dijeran cómo dibujarían ustedes este 2011

(CCEC Med12<TePe2811)

'Before saying to you goodbye and appreciating that you have shared your time with us, we should ask to tell us how you (postv.) would draw this year, 2011'.

Cognitive salience and informativeness have been revealed as very important tools to explain and analyze the expression and omission of pronominal subjects in Spanish (Aijón Oliva \& Serrano 2013:31-35). The figure below represents the placement of the three possible variants of pronominal subjects along the salience - informativeness continuum.

Omitted subject

+ salient, - informative
Preverbal subject

Postverbal subject

Figure 1. Gradation of the salience and informativeness of omitted, preverbal and postverbal subjects

Being gradual dimensions of cognitive meanings, each variant accounts for creating a variable orientation towards either the subjectivity or objectivity pole. A discourse based on participants or on subjects introducing the personal viewpoint of the speaker will tend to produce a subjective meaning style (cf. Finegan 1995: 1). Objectivity results from a discourse performed on objects by diminishing the salience of subjects. As a counterpart of subjectivity, it is the extent to which a linguistic entity is construed as the object versus the subject (Langacker 1994: 15-16) (v. Aijón Oliva \& Serrano 2013:143-149). The omitted variants would tend to create objective styles, whereas expressed subjects would contribute to accomplish subjectivity.

Furthermore, a grammatical person may also be disposed alongside the subjectivity-objectivity continuum, as will be explained next.

\subsection{Tú and usted in the cognitive continuum}

The cognitive approach involves an indissoluble relation between form and meaning presupposing that linguistic forms are choices by themselves. Thus, their status in the speaker's perception and their possibilities of creating diverse meanings must be observed. Grammatical persons constitute an idoneous field to demonstrate that each form enacts a different perspective of the referent they indicate from a cognitive basis. The first-person singular yo ('I') represents the primary perspective of the speaker, whereas the plural nosotros ('we') widens such a perspective to a human group, albeit one whose specificicity is very variable (Serrano 2011). The second 
person detaches the discourse from the speaker's own sphere, and it may index to an interlocutor or rather to a non-specific or general referent, as is the case of the objectivizing second-person tú (Serrano \& Aijón Oliva 2012, 2014). ${ }^{2}$

Regarding usted, its consideration as a simple formal or polite synonym of $t u$ that has been supported not only by the intuition of most speakers but also has been set forth in many traditional grammars and handbooks of Spanish (e.g. Alarcos 1999:76-77, Miñano López 2007:171, among others). Its historical origin as a nominal phrase with polite meaning (vuestra merced) is analogous as other third persons still used nowadays (su señoría, su excelencia), and this reveals that usted should be considered as part of a third-person category, entailing an indirect way to index the interlocutor. The inherent third-person reference of usted bears a remarkable contrast with the perspective endowed by the second person. In fact, its extradiscursive deixis is what has made it possible to add this pronoun to the second-person paradigm. Besides, its syntactic behaviour, such as its frequencies of expression vs. omission, is certainly closer to nominal phrases than the rest of the pronouns. On the basis of these particularities, García (2009: ch.1) has included this form in a category labelled ' $I T$ ', situated in between the second- and the third-person pronouns.

From the inherently variable perspective of the linguistic system, the first person of the paradigm, yo ('I'), represents the most subjective stance, whereas the third-person and the impersonal structures occupy the notional domain of objectivity. As for the second persons tú and usted, they are placed in the middle of the continuum, the latter being closer to the objectivity pole than the former. The diagram below illustrates the position of each pronoun along the subjectivity - objectivity scale.

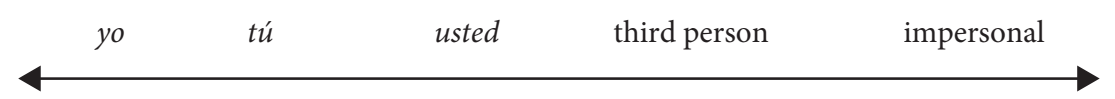

Subjectivity

Objectivity

This distribution is in line with the wider viewpoint of analyzing grammatical persons, as different communicative choices by which a speaker can index his/ herself or the interlocutor/audience during a discourse. Furthermore, the meaning engendered by the choice of $t u$ or $u s t e d$ is shaped by its expressed (preverbal or postverbal) and omitted variants. Any selected variant will concern not only the management of the image of both the speaker and hearer but it will also condition the interpretation of the utterance and even that of the discourse as a whole.

2. The choice of objectivizing the second person is promoted by an intention to dissociate the content of discourse from the particular circumstances, opinions or values of the speaker, suggesting instead that what is being said somehow affects or could affect the hearer as well: 'Cuando llegas a tener mucho dinero, no sueles acordarte de tus amigos' 'When [you] get to earn a lot of money, [you] don't usually remember your friends' (Serrano \& Aijon Oliva 2014:228). 


\section{Methodology}

The analysis of $t \dot{u}-u s t e d$ variation will be based on the materials from an oral corpus called Corpus Conversacional del Español de Canarias, which comprises two different sections: one of spontaneous face-to-face conversations (79,544 words) and another containing texts from different regional TV and radio programmes classified as news programmes, informative-debates, talk shows and magazines (171,258 words), on which the present research is focused. The characteristics of each category are as follows:

- News programmes (55,474 words). These informative programmes cover the usual kinds of subjects in media information (politics, sports, weather, etc.).

- Informative-debates (41,753 words). This genre combines news items and the discussion of different views, often opposing, on various subjects.

- Talk shows (12,685 words). This genre is devoted to commentary on current events, generally in a friendly, non-contentious fashion.

- Magazines (61,346 words). These combine a wide variety of information and entertainment materials.

The speakers have been divided into four categories labelled socioprofessional affiliations on the basis of the communicative function played in the mass media genre where they take part:

a. Journalists. The professionals of mass-media communication.

b. Politicians. Speakers presenting themselves as political-party representatives.

c. Public figures. Professionals who participate in media texts as entrepreneurs, artists, sportspeople, advertisers, representatives for companies and associations, etc.

d. Private individuals. A variety of speakers who take part circumstantially in media interactions.

This variety of texts and socioprofessional identities of speakers will allow us to observe and study the use of $t u$ and usted in its proper contexts of use. This variation will first be measured by calculating the percentages of their expressed and omitted variants. They will also be approached as absolute variables, calculated as the number of occurrences of each form per 10,000 words of text within each genre or socioprofessional category. The treatment of linguistic phenomena as absolute variables is based on the assumption that any pairing of form and meaning is contextually chosen for its own value and not just as opposed to any other options (Aijón Oliva \& Serrano 2013:64-67).

This methodology will be aimed at demonstrating the extent to which this case of variation and the meaning created by each pronoun and its variants (on the basis of the cognitive properties described in 2.2.) is unevenly distributed in certain speech situations and by different speakers to accomplish concrete communicative goals. 


\section{The variable expression of $t u$ and $u s t e d$}

A quantitative analysis of the overall expression and omission of the pronouns tú and usted indicates that the omitted variant is the most frequent, following the general tendency of the Spanish language (Aijón Oliva \& Serrano 2013:76, Enríquez 1984; Silva-Corvalán 2001, among others). However, it is remarkable that the expression of usted is slightly higher than that of tú.

Table 1. Omission and expression of tú and usted

\begin{tabular}{llrl}
\hline & Omission & Expression & Total \\
\hline Tú & $157(69.2 \%)$ & $70(30.8 \%)$ & 227 \\
Usted & $181(62.4 \%)$ & $109(37.6 \%)$ & 290 \\
\hline
\end{tabular}

The tendency of using expressed usted may be explained on the basis of its formal and notional closeness to the third-person nominal phrases (v. supra). Entities formulated as third-person forms are less salient than direct participants; therefore, their deictics do not singularize them among other possible referents, and speakers should promptly clarify them during discourse. It can be hypothesized that less salient elements would be out of the speaker attention scope and tend to be formulated, expressed or even repeated. Although the grammatical nature of usted may explain its higher frequency of expression (Keniston 1937: 150; Rosengren 1974:25; Serrano 2012: 17), some interactional factors exist that also favour its formulation. Most examples of the expression of usted seem to have not been necessary from the sole perspective of referent identification; instead, they reveal an interest of the speaker to stress the involvement of the interlocutor in the content, to attract his/her attention or even to request his/her cooperation. In example (4), it can be observed that the pronoun usted is expressed in the first clause and repeated unnecessarily in those that follow.

(4) Presenta usted una nueva denuncia con su sentencial|||insistir en que se ejecute la sentencial ¿en el año 2000 fue?/en el año que puso usted la denuncialpues esa sentencia que tiene usted del $2003 \varnothing$ intente que se ejecute por todos los medios posibles $\$

(CCEC Med12<ElEnv1011>)

'You (postv.) have to file a new lawsuit based on the sentence ... Was it in 2000 that you (postv.) filed your lawsuit? Then that sentence you've (postv.) had since 2003, [you] must try to get it carried out' 


\subsection{The variable placement of tú and usted}

As for the preverbal or postverbal placement, tú and usted display strong yet different tendencies. The frequencies of $t u$ ('you') indicate that it commonly tends to be placed in the preverbal position, whereas the frequency of the postposition of usted is considerably higher than that of $t u$ ( $33.1 \%$ vs. $7.1 \%)$. Usted has shown a noticeably distinct syntactic behaviour from that of first- and second-person pronouns (Sánchez López 1993:262) and exhibits a notable tendency to be placed after the verb.

Table 2. Preverbal and postverbal placement of tú and usted

\begin{tabular}{lccc}
\hline & Preverbal & Postverbal & Total \\
\hline Tú & $65(92.9 \%)$ & $5(7.1 \%)$ & 70 \\
Usted & $73(66.9 \%)$ & $36(33.1 \%)$ & 109 \\
\hline
\end{tabular}

The variation in the prototypical order of constituents would reveal pragmatic values (Geluykens 1992:83-96; Hidalgo Downing 2003: 12). On the basis of this logic, the higher salience of the second-person tú is related to its tendency to appear in preverbal position, following the non-marked prototypical order SV. The subject initiates an energy flow ending in the patient (Langacker 1991); then, direct participants in the discourse (such as tú) and human and agentive elements are expected to be codified as subjects, and tend to occupy the preverbal position (Branigan et al. 2008). On the contrary, the lesser salience of usted, its notional characteristics (assimilated as noun phrases) and the increasing informativeness it conveys could promote its codification as an object, which would explain its tendency to appear in postverbal position. This facilitates interpreting the pronoun as contrastive, unexpected or pragmatically focused. These pragmatic values can be observed in examples (5), (6) and (7), where usted is formulated after the verb.

(5) Buenas noches $\backslash$ dice usted que ha habido consensolpues Dios le guarde ese consensoleso ha sido idea suyalyo ya le he dicho que el consenso es el plenol (CCEC Med12 <ElEnv2611>)

'Good night, you've (postv.) said that it was a consensus, but may God save such a consensus, this was your idea, I only said that the consensus is the plenary'.

(6) $\varnothing$ Tiene inquietudes en el mundo de la músicalØ siempre las ha tenido $\$ en el campo de cantautor presenta usted $\backslash$ tanto aquí como en Madrid una especie de formato nuevolCanarias pueblo Canarias canciónly $\emptyset$ también toca otras especialidades (por llamarlo asílfue la época de los cantautores ¿qué recuerdos tiene $\varnothing$ de esa época?/

(CCEC Med12<DiTag99>) 
'[You]'re interested in music - [you]'ve always been. As a singer - songwriter you (postv.) are introducing, here as well as in Madrid, some kind of new format ... and $[y o u]$ also tackle other areas. We can say that was the singer songwriter period. What memories do [you] keep from those days?'

(7) Y por la mañanalademás de este excepcional programaltienen ustedes la compañíalde una mujerlexcepcional también \no vean la de cosas que tiene que contarnoslescuchenlescuchen $l_{\dot{ }} \varnothing$ lo apuntaron $\backslash$ no?!

(CCEC Med 12<Vimige212>)

'In the morning, together with this exceptional program, you (postv.) can count on the company of an equally exceptional woman. Just imagine how many things she has to say. Listen, listen. Did [you] write everything down?'

Even though expressed subjects generally promote a meaning based on informativeness and thus lead to subjectivity, such meaning will be conditioned by the placement of the subject in the clause; preverbal pronouns are more salient and less informative, whereas postverbal pronouns are more informative and less salient, this position being farther from the prototypical SV order in Spanish (See Figure 1). The cognitive - discursive features of the expressed (preverbal and postverbal) and omitted variants of tú and usted will serve to create meanings in different communicative situations and by different social groups.

\section{The sociosituational variation of $t u$ and usted and the construction of communicative styles}

Most studies related to the choice of $t u$ or $u s t e d$ have considered it an issue merely correlated with extralinguistic factors ( $c f$. Almeida et al. 2006; Nowikow 2010; v. Medina Morales 2010:27-31). This research attempts to go beyond such a view by delving into the discursive and cognitive traits that underlie this variation. We depart from the idea that speakers not only select one or another form on the basis of possible conditioning external factors but most importantly, they choose the meaning they consider to be more appropriate for the accomplishment of their communicative goals. Thus, far from explanatory traditional notions such as power or solidarity, this analysis will pursue a more realistic view of communicative processes by way of the study of the forms as used in several mass media genres and by the participants who take part in them. In this line, Morford (1997) has contributed to overcome such an approach by applying a new framework to the study of address terms in French based on social indexicality (Silverstein 2003) that will be useful for explaining some results of the present research. 
Tú and usted are analyzed as absolute variables (see Section 2). The calculation of the normalized frequencies (calculated as the number of occurrences per 10,000 words of text) across genres and socioprofessional affiliations provides a representation of the capacity for each form to communicate something by itself and not only through the so-called opposition between them. I depart from the assumption that speakers do not only choose address terms according to their supposedly predeterminate meaning but also actively participate in the construction of such a meaning (van Compernolle 2011:87).

\subsection{Textual genre}

The distribution of tú and usted by textual genre reveals that there is unequal usage across them. To begin with, tú is most commonly used in magazines and talk shows. The frequency of usted usage shows that it is more likely to occur in informative-debates.

Table 3. Absolute frequency of tú and usted by textual genre

\begin{tabular}{|c|c|c|c|c|}
\hline & \multicolumn{2}{|l|}{$T u ́$} & \multicolumn{2}{|l|}{ Usted } \\
\hline & Occurrences & Frequency & Occurrences & Frequency \\
\hline $\begin{array}{l}\text { News programmes } \\
\text { ( } 55,474 \text { words) }\end{array}$ & 24 & 4.3 & 44 & 7.9 \\
\hline $\begin{array}{l}\text { Informative-debates } \\
\text { ( } 41,753 \text { words) }\end{array}$ & 35 & 8.3 & 145 & 34.7 \\
\hline $\begin{array}{l}\text { Talk shows } \\
(12,685 \text { words })\end{array}$ & 16 & 12.6 & 15 & 11.8 \\
\hline $\begin{array}{l}\text { Magazines } \\
\text { (61,346 words) }\end{array}$ & 152 & 24.7 & 86 & 14 \\
\hline
\end{tabular}

Magazines are interactive oral genres in which a variety of topics are dealt with, normally regarding present-day matters and usually developed in a friendly manner. This should require a firsthand relationship between participants that facilitates the communicative exchange. Therefore, the most suitable option to index the interlocutor in these situations is the prototypical second-person tú.

(8) [Magazine]

Tú bien sabes que un telescopio no es solo una cúpula y espejos/ sino que están los instrumentos que lo formanl

(CCEC Med12<GalyCent 310>)

'You know full well that a telescope is not only a dome and a sphere but that there are also the instruments that form it' 
(9) [Magazine]

Precisamente hoy nos hemos venido aquí al muelle de Corralejo\Andrés/tú eres el patrón de este veleroldinos cómo se activarían las alarmas en caso de emergencial

(CCEC Med12 <CanDi 141>)

'We have just precisely come here to the Corralejo dock, Andrew you are the captain of that sailing boat, tell us how the alarms would be activated in an emergency situation'

In a similar way, the absolute score of tú obtained in talk shows reflects that the speaker needs to be closer to the interlocutor or audience according to the dialogical and interactive nature of this genre, and this would explain the tendency of speakers to choose this pronoun. Moreover, the nature of these interactions promoting the choice of $t u$ would be considered as a first-order indexicality as it index pragmatic aspects of this kind of communicative situations that contribute to entail the meaning created (Morford 1997: 16).

(10) [Talk show]

A. Pero tú crees que el árbitro estuvo prepotentelperol ¿por qué crees que estuvo prepotente?/ ¿pero tú le insultaste?/

B. No lo pude evitar/cuando se acabó la lucha... (lucha canaria)

A. ¿Tú crees que vas a ser sancionado?/

B. Yo espero que nol

(CCEC Med12 <LaRev2910>)

A. 'But, do you think that the referee was conceited but, why do you think he was conceited? Did you insult him?

B. I couldn't avoid it, when the fight ended (Canarian fighting)

A. Do you think you are going to be penalized?

B. I do not expect that'

In both types of text, the notable frequency of $t u$ indicates that the meaning of the second-person pronoun chosen in these texts implies the performance of a more subjective communicative style than other options, as its relative position on the continuum indicates (See fig. 1). The cognitive properties of this pronoun entail a higher degree of subjectivity than usted and generate a meaning on the basis of the direct allusion to the interlocutor, associating the textual content with his/her own personal circumstances.

However, it must be noted that the frequencies of tú and usted in talk shows are very close ( 12.6 for $t u$ and 11.8 for usted), which would indicate that there is no striking preference for using one or the other form in that genre, probably because of the variety of topics addressed and the wider range of speakers who participate in it. In fact, the changes in the features of texts and communicative situations are of a gradual nature (cf. Biber \& Conrad 2009). As sets of more or less 
commonly shared linguistic features, genres are of a gradual nature, have no clear boundaries and there would be a kind of intertextuality or genre mixing among them (Theodoropoulou 2014: 7-13, 97).

Besides, usted is used more in the informative - debate programmes, which combine news information with subsequent commentary and discussion. The exposition of speakers' own ideas and opinions in a trusting way is consistent with the indexation of the interlocutor by the pronoun usted, which promotes a higher degree of objectivity than $t \dot{u}$, as we have argued. The iconic cognitive distance from the interlocutor inherent to usted enables the exposition of arguments including those that might be controversial, from an objective perspective.

(11) [Informative-debate]

Podemos decir que después de un año de receta electrónica/podemos decir que esto no está implantadolsi yo tengo 16 cápsulas de amoxilina y usted me dice a mí que yo tengo que darle esas cápsulasldígame usted a míl

(CCEC Med12<RoyCo222>)

'After one year period of electronic prescriptions, we can say that it is not really instituted, if I have 16 amoxiline capsules and you say to me that I have to give him/her those capsules, you (postv.), tell me'

(12) [Informative-debate]

Teniendo en cuenta que usted ha sido concejal de tráfico me gustaría saber qué opina sobre el cuerpo de Policía de La Lagunal

(CCEC Med12<ElEnv172>)

'Taking into account that you have been the city councillor for traffic, I would like to know your opinion about the Police Department of La Laguna'

Thus, far from the traditional association with power, formality or polite dimensions, the usage of usted in these texts can be explained by the specific communicative goal required to be performed by speakers; they can boldly present their arguments - some of which may not be shared by the audience - by addressing the interlocutor with the most indirect second-person pronoun, providing a kind of distance that prompts the interpretation of arguments in a more objective fashion. This would be the case with the indexation of the interlocutor usted in the following example.

(13) [Informative-debate]

La reforma que se propone en el sistema educativo no va a triunfarlno va a eliminar los actuales problemasldiga usted a quién beneficia que los chicos tengan que venir un año más।

$($ CCEC CanDi<212>) 
'The proposed reform of the educational system will not be successful, it is not going to eliminate the existing problems $\$ say you (postv.) who benefits from the fact that children must attend school one more year'

\subsection{Socioprofessional affiliation of speakers}

As the textual genre analysis showed, the social functions played by speakers in interactions reflect that $t u$ and $u s t e d$ are distinctly used because of the meanings that each form draws. In the multimodal framework of variation analysis adopted in this research, a conjoined action of factors is considered, thus the second-person indexation across the participants' socioprofessional affiliations is related to the textual genres in which they most often participate. Table 4 displays the distribution of both pronominal choices in every category.

Table 4. Absolute frequency of tú and usted by socioprofessional affiliation of speakers

\begin{tabular}{|c|c|c|c|c|}
\hline & \multicolumn{2}{|l|}{ Tú } & \multicolumn{2}{|l|}{ Usted } \\
\hline & Occurrences & Frequency & Occurrences & Frequency \\
\hline $\begin{array}{l}\text { Journalists } \\
(63,739 \text { words })\end{array}$ & 105 & 16.4 & 181 & 28.4 \\
\hline $\begin{array}{l}\text { Public figures } \\
\text { (46,661 words) }\end{array}$ & 29 & 6.2 & 11 & 2.3 \\
\hline $\begin{array}{l}\text { Politicians } \\
(38,340 \text { words) }\end{array}$ & 36 & 9.3 & 87 & 22.6 \\
\hline $\begin{array}{l}\text { Private individuals } \\
(22,518 \text { words })\end{array}$ & 57 & 25.3 & 11 & 4.9 \\
\hline
\end{tabular}

Here, we can see that there are remarkable differences in indexation among socioprofessional affiliations of speakers. Private individuals show a higher frequency of indexation through the pronoun tú. These speakers are usually requested by the presenter of the program to contribute with their opinions or experiences about the topics dealt with. Given that this pronoun tends to enhance the subjective style, it is comprehensible for this group of speakers to use the pronoun tú more often to accomplish a communicative goal of this type. Moreover, they do not have the responsibility of offering an image of themselves in mass media communication, as other socioprofessional groups do; hence, this explains the disinclination of private individuals to use the objectivization resource offered by the alternating pronoun usted.

In the following dialogue during a radio program between a journalist and a private individual, the journalist initiates the conversation employing the omitted 
pronoun usted (¿De dónde $\varnothing$ llama amigo? 'Where are you calling from?'); however, he switches to tú upon noticing that his interlocutor has used this pronoun.

(14) [A: Journalist; B: Private individual]

A. ¿De dónde $\varnothing$ llama amigo?

B. Del Puerto de la Cruz

A. ¿Y usted se llama...?

B. Pedrolyo quería decir que eso de las matronaslyo tengo edad para saber qué son las matronaslporque tú sabes que antes las matronas iban a las casas

A. ¿Tú sabes lo que son las matronas?

B. No lo vivílpero sí que lo sé

(CCEC Med12<LaAlp212>)

A. 'Where are you calling from?

B. From Puerto de la Cruz

A. And... what is your name?

B. Pedro, I want to talk about midwives, I'm old enough to know what midwives are because you know that earlier the midwives went to homes

A. But, do you know what midwives are?

B. I did not experience it but I do know what they are'

Notwithstanding, it would also be possible for the pronoun used by the journalist to condition the one used by the interlocutor; in the following dialogue, the private individual participating in this conversation has answered the questions using tú, the same pronoun the journalist made the request with.

(15) [A: Journalist; B: Private individual]

A. ¿Estás ahora mismo cerca del Belén?/

B. Sí/dime $\varnothing$ qué quieres saber/

A. Yo tengo un problema/porque me identifico con dos figuritas del Belén/

B. ¿Con qué figuritas te identificas tú?

(CCEC Med12 <LaAlp212>)

A. Are you right now close to the nativity scene?

B. Yes, tell me what you want to know

A. I have a problem, because I identify with two of the nativity scene's statues

B. With what statue do you identify with?

Conversely, journalists and politicians clearly show the strongest rates of $u$ sted. Albeit turning out a resource to index the interlocutor in a more objective fashion, a different motivation for this choice can be predicted for each group. The frequency of usted among politicians is in concordance with the same frequencies obtained in informative-debates, a genre in which they often participate. Politicians and informative-debates are professional and situational circumstances where argumentative discourse is expected to arise. Whether this choice reflects the 
contextual status acquired by these social categories, it would be the result of a second-order indexicality (Morford 1997: 16). Therefore, the 'oriented-to-objectivity' meaning performed by this pronoun produces results suitable to them, as it presents arguments iconically distant from the interlocutor or audience, given that they would be subject to controversy or would not always be expected to be shared by them (See examples 16 and 17).

(16) [Politician]

Se lo diré muy brevementelusted dice que vienen años muy difícilesly usted dice/pero yo no veo que se esté haciendo algo con los bancos\

(CCEC Med12<ElEnv272>)

'I will say to you briefly, you say that difficult years are to come and you say... but I do not notice that anything is going to be done with banks'

(17) $[$ Politician $]$

$\varnothing$ Ha criticado/lo que usted antes decía/ que está fuera/con un partido casi marginal/¿usted cree que se puede seguir y gobernar con esa actitud?/

(CCEC Med12<ElEnv212>)

'[You]'ve criticized what you yourself said before: the fact of being in an almost marginal party. Do you really think it is possible to stay in office with such an attitude?'

In addition, the recurrent use of usted among politicians supports the general idea that this is the most acceptable pronoun employed by this socioprofessional affiliation. The occasional shift to tú in the discourse of a politician may cause negative and rather blameworthy reactions among interlocutors or the audience (Medina López 2009: 82) ${ }^{3}$ probably because the content of the speech of a politician is expected to be performed as objectively as possible. Some important findings have shown that pronominal choices in political discourse are usually made to

3. During the 2007 Spanish electoral campaign, President Zapatero participated in a TV debate. In his speech, he was alternating between the use of usted and tú in some sentences like 'Le agradezco que me hagas estas preguntas'/ 'I must express [you. frml] my gratitude for [you] to put those questions to me'. Such pronoun shifting brought on many negative reactions in newspapers and social networks; the use of tú instead of usted was labelled as 'too close', 'too colloquial', 'backscratching', 'non-respectful', etc. (cf. Medina López 2009: 82-83). The perspective assumed in the present research would explain such a choice of $t u$ in this context as a feature of style that subjectivizes the content. Although this is worthy of deeper analysis, it should be hypothesized that in the course of his speech the President was choosing either tú or usted on the basis of the nature of the topics or questions being posed by the audience, thus the most personal or subjective inquiries would be answered with $t \dot{u}$, whereas the more institutional ones and therefore expectably more objective (as those about the future political tasks he was expected to perform) would be replied with usted. 
accept or reject responsibilities (Beard 2000; Blas Arroyo 2000; Fairclough 1989; Pennycook 1994; Wilson 1990; Zupnik 1994) and tend to configure a particular style of participant. It has been demonstrated that usted (and its plural ustedes) is the most expectable second-person pronoun in political discourse, its basic communicative function being to criticize the interlocutor in political debates or 'to refer critically to the subjects of certain actions' (Blas Arroyo 2000:10-13). Thus, by indexing an interlocutor or audience with this choice, politicians would be avoiding the subjectivity attached to $t u$, and this will help in the construction of a discourse primarily oriented toward objectivity.

On the other hand, the preference showed by journalists to choose the objective meaning of usted might be interpreted as a way to shape a self-image of credibility and seriousness, suggesting neutrality towards the contents exposed, since one of their communicative goals should be the construction of a particular kind of professional identity of objectivity. The tendency of journalists to create objective styles has been corroborated in some other studies about syntactic choices (cf. Aijón Oliva \& Serrano 2013: 191). The following excerpts instantiate some inquiries made by journalists with the pronoun $u$ sted.

(18) [Journalist]

¿Usted, qué consejos le daría al partido socialista?/¿Usted cree que será capaz de sacar el país adelante?

(CCEC Med12<Re71012>)

'What advice would you give to the socialist party? Do you think it will be capable of getting this country ahead?'

(19) [Journalist]

Díganos usted cómo negocia el precio que le dice el proveedor/usted ve el precio que le dan y ya negocia /ies así?

(CCEC Med12<Re71012>)

'Tell you (postv.) us how do you negotiate the price with the seller, you see the price they give you and negotiate, right?'

\section{Sociosituational variation of the expression and omission of $t u$ and usted}

Notably, the tendency of tú and usted to create styles on the basis of the dimensions of subjectivity or objectivity will be gradual, which is based on the possibility of these pronouns to appear as expressed (preverbal or postverbal) or omitted. ${ }^{4}$ As

4. Previous research has concluded that politicians as a socioprofessional affiliation tend to create a subjective style based on their tendency to express pronominal subjects (Aijón Oliva \& Serrano 2013:204-205). 
shown in Section 2.1, the properties of salience and informativeness of the omitted, preverbal and postverbal subjects are gradually applied according to the continuum where they are placed.

A relative analysis by percentages of the second-person singular tú and usted (See Section 2) will help to specify their capacity to perform different communicative styles.

\subsection{Expression and omission of tú}

As would be expected, the omitted variant of tú is the most frequent in all genres. The preverbal placement occurrences are higher than the postverbal, which did not result in being representative at all.

Table 5. Expression vs. omission of tú by textual genre

\begin{tabular}{lclrl}
\hline & Preverbal & Postverbal & Omitted & Total \\
\hline $\begin{array}{l}\text { News } \\
\text { programmes }\end{array}$ & $7(29.1 \%)$ & $1(4.2 \%)$ & $16(66.7 \%)$ & 24 \\
$\begin{array}{l}\text { Informative- } \\
\text { debates }\end{array}$ & $16(45.7 \%)$ & 0 & $19(54.3 \%)$ & 35 \\
$\begin{array}{l}\text { Talk shows } \\
\text { Magazines }\end{array}$ & $7(43.8 \%)$ & 0 & $9(56.2 \%)$ & 16 \\
\hline
\end{tabular}

However, the higher occurrence of the omitted variant in news programmes and magazines can be explained as the latter being the genre where tú is most used (See Table 3). Its interactional and dialogical nature implies that the referent of the subject is salient; hence, there is no need to formulate it. In the following example, the journalist is speaking with someone who is participating in the programme, thus the pronoun can be omitted because its referent is already accessible or cognitively salient.

(20) [Magazine]

Decía si $\varnothing$ estás en tu despacho porque seguro que $\varnothing$ tienes una minicadena donde $\varnothing$ oyes Roscas y Cotufas $\quad$ (CCEC Med12<RoyCo308>) 'I was saying that you are in your office because you surely have a mini hi-fi to listen Roscas y Cotufas'

On the other hand, the incidence of omission in news programmes genre is due to the scarce participation of people in real time just because its communicative purpose is oriented to expose information, normally about recent news. The second-person indexation is normally referred to as an imaginary hearer who is not present, as observed in (21). 
(21) [News programme]

$\varnothing$ Has acertado $\varnothing$ ya sabes dónde encontrarnoslen Canarias Radio la Autonómical

(CCEC Med12<CanDi2211>)

' $[Y o u]$ are right, $[y o u]$ just know where to find us, at Canarias Radio la Autonómica'

For its part, the higher score of preverbal expression in informative-debates and talk shows is consistent with their argumentative goals: indexing the second person - normally present in these interactions - by the expressed pronoun stresses the content on the referent, loading it as a protagonist of the utterance. See example (22).

(22) [Informative-debate]

Vamos a hablar de esa muerte repentina en la que tú como bien dijiste ha llegado un poco prontol

(CCEC Med12<ElEnv2211>)

'Let's talk about that sudden death, which as you have said, has come too rapidly'

The socioprofessional affiliations of speakers also reveal that omission is the variant preferred by all categories, but it is remarkable that public figures and private individuals make more use of them than the other groups. The preverbal variant percentages indicate that politicians, followed by journalists, primarily use it. Again, the results show that postverbal position is not significant.

Table 6. Expression vs. omission of tú by socioprofessional affiliation of speakers

\begin{tabular}{lrllc}
\hline & Preverbal & Postverbal & Omitted & Total \\
\hline Journalists & $32(30.5 \%)$ & $2(1.9 \%)$ & $71(67.6 \%)$ & 105 \\
Public figures & $4(13.8 \%)$ & 0 & $25(86.2 \%)$ & 29 \\
Politicians & $15(41.7 \%)$ & $1(2.8 \%)$ & $20(55.5 \%)$ & 36 \\
Private individuals & $14(24.5 \%)$ & $2(3.5 \%)$ & $41(72 \%)$ & 57 \\
\hline
\end{tabular}

There is a notable frequency of the preverbal variant of tú in those genres whose communicative goals are oriented to a more personal or argumentative fashion, such as informative-debates and talk shows. Given that tú promotes a meaning based on + salience and - informativeness (See Figure 1), it would lend support to the idea that its usage in these texts and by those socioprofessional affiliations contributes to the shaping of a communicative style based on subjectivity. Moreover, its relevant presence in the speech of politicians and journalists may be explained on the basis of the textual genres where they usually participate: politicians make use of the expressed variant to perform their argumentative contents. In example (23), a politician intends to answer someone who intended to get information about something by indexing him with the expressed preverbal pronoun $t u$. 


\section{(23) [Politician]}

Siempre hemos reivindicado el tema de protecciones en las vallas $\backslash$ tú me querías preguntar cuál sería la solución para evitar esas muertes\}

(CCEC Med12<CanDi2211>)

'We have always claimed the matter of protecting fences, you wanted to ask me what would be the solution to avoid these deaths'

Journalists may index the interlocutor by means of the expressed preverbal variant to pursue concrete goals, such as obtaining more information on a concrete subject, similar to that about the weather, as in (24).

(24) [Journalist]

Lo que sí se ve es que vamos a tener una semana con tiempo del estelyo no sé si tú recuerdas un invierno tan secol

(CCEC Med12<BDC91>)

'It is clearly observed that we are going to have an east weather week, I do not know if you remember a winter as dry as this'.

The distribution of the expression and omission of the variants of $t u$ indicates that although the omitted pronoun is the prevailing variant, the preverbal placement of this pronoun is somehow frequent in those communicative situations that may require a slight increase of subjectivity, as in informative-debates and talk shows. Similarly, politicians and journalists make use of this variant when they find it necessary to accomplish more subjectively guided communicative goals.

\subsection{Expression and omission of $u$ sted}

Regarding the variation of usted, it can also be observed that the omitted variant is strongly used in all genres. Similar to those obtained for $t \dot{u}$, higher scores were found for usted in magazines, closely followed by talk shows.

Table 7. Expression vs. omission of usted by textual genre

\begin{tabular}{lcclr}
\hline & Preverbal & Postverbal & Omitted & Total \\
\hline News programmes & $15(34 \%)$ & $7(16 \%)$ & $22(50 \%)$ & 44 \\
Informative-debates & $63(43.5 \%)$ & $29(20 \%)$ & $53(36.5 \%)$ & 145 \\
Talk shows & $3(20 \%)$ & $2(13.3 \%)$ & $10(66.7 \%)$ & 15 \\
Magazines & $20(23.2 \%)$ & $8(9.3 \%)$ & $58(67.5 \%)$ & 86 \\
\hline
\end{tabular}

The accessibility or salience of the referents would again be the primary reason for these interactional genres to not show considerable frequencies of the formulation of the pronoun $u$ sted. 


\section{(25) [Magazine]}

Consejera/ ¿Ha podido Ø ver los carteles de los ganadores?/después le voy a preguntar por ellol

(CCECMed12<LaAlp212>)

'Minister, have you seen the winner's posters? I am going to ask you about it later'

As suggested, the obtained rate of expressed (preverbal and postverbal) usted in all the genres is noticeable, especially in informative-debates and news programmes. Given that the meaning of this pronoun promotes objectivity by its inherent properties, the expressed preverbal variant would constitute just a slight downplaying of this objectivity justified by some concrete goals of these texts, as indexing the interlocutor to make him responsible for the content. See examples (26) and (27).

(26) [Informative-debate]

Usted ha leído la información de empresas que no sobrevivirán|pero es que la reforma laboral no se ha hecho bienl

(CCECMed12<BDC132>)

'You have read the information about businesses that will not last, but the labour reform has not been done well'.

(27) [Informative-debate]

Usted ha hablado que se aumente la subvención para las potabilizadoras\ (CCECMed12<BDC132>)

'You have talked about increasing the subsidy for water-treatment plants'

Usted shows a greater tendency than other pronouns to be placed after the verb (Serrano 2012:116). In this position, the formulated pronoun usted increases the pragmatic underlining of its referent, which is particularly noticeable in questions (See 28). Through its cognitive properties (- salient, + informative, see Figure 1), this option is considered not to promote an objective style as the omitted variant would do.

(28) [News programmes]

Por lo que nos cuentales un éxito rotundo la huelga en la refineríal ¿cree usted que el gobierno tomará nota?/

(CCEC Med12<BDC293>)

'As you have told us, it is a definitive success the refinery strike, do you [postv.] believe that the government will take note of it?'

Regarding the distribution of usted by socioprofessional groups, they all prefer using its omitted variant. However, politicians and journalists reach significant scores of the expressed preverbal variant, and there is a notable increase of the use of the postverbal variant, especially among politicians.

These results corroborate the idea that this pronoun is used most by journalists and politicians, although for different reasons (See 6.2). By analyzing this pronoun as a relative variable, these groups can be inferred to take advantage of 
Table 8. Expression vs. omission of usted by socioprofessional affiliation of speakers

\begin{tabular}{lcccc}
\hline & Preverbal & Postverbal & Omitted & Total \\
\hline Journalists & $65(36 \%)$ & $28(15.4 \%)$ & $88(48.6 \%)$ & 181 \\
Public figures & $2(18 \%)$ & $2(18 \%)$ & $7(63.6 \%)$ & 11 \\
Politicians & $38(43.6 \%)$ & $26(29.8 \%)$ & $23(36.4 \%)$ & 87 \\
Private individuals & $1(9 \%)$ & $1(9 \%)$ & $9(82 \%)$ & 11 \\
\hline
\end{tabular}

the meaningful potential offered by usted. By means of the objective meaning portrayed by this form, journalists may construct a self-image of seriousness and professionalism, primarily required to develop their communicative tasks. Besides, using the preverbal and postverbal placement of this pronoun allows them to modulate the meaning that is intended to be communicated in particular utterances. For example, in the following dialogue between a journalist and a politician about the possibility of becoming the Prime Minister, the journalist uses the preverbal variant of usted to introduce information presupposed by him directly concerning the politician. The use of this variant diminishes the objectivity normally conveyed by this pronoun as shown in (29).

(29) [A: Politician; B: Journalist]

A. Mucha gente creía que yo aspiraba a presidenta del gobiernoly he dicho que síl

B. Pero algunos dicen que usted va por el camino de castigar

A. Nolyo de momento voy premiadalel partido quiere que vayal

(CCEC Med12<ElEn103>)

'A. So many people believed that I was aspiring to be Prime Minister and I have said "yes"

B. Yes, but some people say that you go in the direction of punishment

A. No, at the moment I go awarded, the party wants me to go'.

On the other hand, the argumentative discourse usually performed by politicians explains the fairly equal use of the three variants of usted among them. However, the slight downplaying of objectivity promoted by the preverbal expression may also serve to enhance the positive or dignifying image of the referent. Note this implication in (30).

(30) [Politician]

El pueblo herreño que ha sido muy responsablelestará muy pendiente hoy de lo que usted les pueda decirldesde la Restinga y también aquellos que fueron evacuados de El Golfol

(CCEC Med12<ETT26111>)

'The El Hierro people - who have been very responsible - will be watching for what you can say to them, from La Restinga and also those who were evacuated'. 
The postverbal position, being closer to objectivity than the preverbal, stresses the referent in a more conspicuous way, displaying meanings that can be interpreted in that way. In (31), by means of the postposition of the pronoun usted, the politician makes his interlocutor responsible for a meeting that was troublesome.

(31) [Politician]

El gabinete ha parado las negociaciones tras la reunión que mantuvo usted con representantes de cultural

(CCECMed12<LaAlp212>)

'The cabinet has stopped the negotiations after the meeting you [postv.] held with culture's representatives'

In (32), the question posed by the politician to another politician is focusing on the referent of the pronoun (Mr. Soria) to inquire about renting a car when arriving at the airport as a reproachable attitude.

(32) [Politician]

Sr. Soria cuando llega usted al aeropuerto de Madrid Barajasl¿qué le parece a usted coger un coche en el aeropuerto?

(CCECMed12<LaAlp212>) 'Mr. Soria, when you arrive at Madrid-Barajas airport, what do you [postv.] think about renting a car at the airport?'

In both examples, the postposed pronoun involves repercussions in the meaning of the utterance by signalling the pronoun's referent as affected by the verbal lexeme, reinforcing and stressing it, which may indeed be interpreted as a resource to objectivize the utterance content.

\section{Conclusion}

This study has attempted to demonstrate that variation existing between the second-person pronouns tú and usted can be explained not simply as address pronouns but, more accurately, as linguistic forms conveying different meanings that are used as communicative resources to either subjectivize or objectivize the communicative content. This approach to syntactic variation as simultaneously formal and meaningful choice challenges the idea that linguistic forms are quite often the carriers of social values that may be indexical. When speakers choose one of the variants of the pronouns under study (expressed preverbal, expressed postverbal or omitted) they are also selecting the meaning considered to be more suitable to accomplish the concrete communicative goals pursued on the basis of the contextual situation and/or the socioprofessional functions displayed by them. The analysis of the normalized frequencies of this variation in diverse textual genres reveals that $t u$ is more frequent in the most interactional ones such 
as talk shows and magazines, and this is due to the topics dealt with, where both the speaker and the interlocutor tend to subjectivize the content and need to feel closer to each other to better develop their conversational tasks.

However, the overall frequencies of usted indicate that it is more commonly used in informative-debates, primarily devoted to argumentation and discussing breaking news. The distribution of socioprofessional affiliations of speakers are tightly connected with these results: private individuals tend to use tú, not only as a consequence of the mass-media situations in which they participate, most tending to subjectivity, but also owing to the absence of any need to present a self-image in such communicative situations. The opposite is found in journalists and politicians, these being the groups that prefer the use of usted, taking advantage of this choice as a way to objectivize their utterances, as well as to develop particular speaker images in the discourse. These tendencies are also confirmed by the analysis of each pronoun as relative variables. Although the omitted variant remains the most frequent, the variation between the expressed preverbal and postverbal variants gives rise to a slight increase or downplaying of the subjectivity and objectivity inherently performed by tú and usted, respectively. These frequencies entail a parallel social-indexicality pointing to the speaker and the communicative situation in a wider social and communicative order.

To sum up, the sociocommunicative distribution of the variation of tu and ust$e d$ has enabled us to sketch the existence of patterned and situated communicative styles by means of their different inherent cognitive meanings, which have been proved to be at the disposal of speakers to achieve their communicative goals in discursive interaction.

\section{Acknowledgements}

This research has been supported by Proyectos Puente al Plan Nacional de Investigación 2014, Vicerrectorado de Investigación e Internacionalización, Universidad de La Laguna, and by Research Project FFI2013-41250-P, Plan Estatal de Fomento de la Investigación Científica y Técnica de Excelencia, Ministerio de Economía y Competitividad.

\section{References}

Aijón Oliva, Miguel Ángel. 2009. “Tú y usted como estrategias de estilo y persuasión en la comunicación publicitaria." Tonos Digital 18 [www.tonosdigital.com].

Aijón Oliva, Miguel Ángel, y María José Serrano. 2013. Style in Syntax: Investigating Variation in Spanish Pronoun Subjects. Bern: Peter Lang.

Alarcos Llorach, Emilio 1999. Gramática de la Lengua Española. Madrid: España. 
Almeida, Manuel, Juana Rodríguez, and Adela Morín. 2006. "Pronombres de trato y clase social en una comunidad canaria." Revista de Filología de la Universidad de La Laguna 24: 11-24. Ariel, Mira 2001. "Accessibility Theory: An Overview." In Text Representation: Linguistic and Psycholinguistic Aspects, ed. by Teed Sanders, Joost Schilperoord, and Wilbert Spooren, 29-87. Amsterdam: Benjamins.

Ardehali, Paula Elizabeth 1990. "Pronoun Exchange as a Barometer of Social Change." Dialectal Anthropology 15: 82-86.

Beard, Adrian 2000. The Language of Politics. London: Routledge.

Beaugrande, Robert, and Wolfgang U. Dressler. 1997. Introducción a la Lingüística del Texto. Barcelona: Ariel.

Biber, Douglas, and Susan Conrad. 2009. Register, Genre, and Style. Cambridge: Cambridge University Press.

Blas Arroyo, José Luis. 2000. "Mire usted Sr. González...Personal Deixis in Spanish Political Electoral Debate." Journal of Pragmatics 32: 1-27.

Blas Arroyo, José Luis. 2005. Sociolingüística del Español. Desarrollos y Perspectivas en el Estudio de la Lengua Española en Contexto Social. Madrid: Cátedra.

Branigan, Holly P., Martin J. Pickering, and Mikihiro Tanaka. 2008. "Contributions of Animacy to Grammatical Function Assignment and Word Order during Production.” Lingua 118: $172-189$.

Brown, Roger, and Albert Gilman. 1960. “The Pronouns of Power and Solidarity." In Style in Language, ed. by Thomas Sebeok, 253-276. Cambridge: University Press.

Croft, William, and Allan D. Cruse. 2004. Cognitive Linguistics. Cambridge: Cambridge University Press.

Davidson, Brad. 1996. 'Pragmatic Weigth' and Spanish Subject Pronouns: The Pragmatic and Discourse Uses of 'tu' and 'yo' in Spoken Madrid Spanish." Journal of Pragmatics 26: 543-565.

Duszak, A. 2002. Us and Others. Amsterdam: John Benjamins.

Enríquez, Emilia. 1984. El pronombre personal sujeto en la lengua española hablada en Madrid. Madrid: CSIC.

Fairclough, Norman. 1989. Language and Power. London: Longman.

Finegan, Edward. 1995. “Subjectivity and Subjectivisation in Language: An Introduction.” In Subjectivity and Subjectivisation in Language, ed. by Dieter Stein, and Susan Wright, 1-15. Cambridge University Press.

Fried, Mirjam. 2009. "Word Order." In Grammar, Meaning and Pragmatics, ed. by Frank Brisard, Jan-Ola Östman, and Jef Verschueren, 289-300. Amsterdam: Benjamins.

García, Erica C. 2009. The Motivated Syntax of Arbitrary Signs: Cognitive Constraints on Spanish Clitic Clustering. Amsterdam: Benjamins.

Geluykens, Ronald. 1992. From Discourse Process to Grammatical Construction. Amsterdam: John Benjamins.

Giora, Israel R. 2003. Salience, Context and Figurative Language. Oxford: University Press.

Goldberg, Adele. 1995. Constructions: A Construction-grammar Approach to Argument Structure. Chicago: The University of Chicago Press.

Givón, Talmy. 2001. Syntax: An Introduction. Amsterdam: Benjamins.

Gundel, Jeanette K., and Thorstein Fretheim. 2009. "Information Structure." In Grammar, Meaning and Pragmatics, ed. by Frank Brisard, Jan-Ola Östman, and Jef Verschueren, 149160. Amsterdam: Benjamins.

Gundel, Jeanette K., Nancy Hedberg, and Ron Zacharski. 1993. "Cognitive Status and the Form of Referring Expressions in Discourse." Language 69: 274-307. 
Hidalgo Downing, Raquel. 2003. La Tematización en el Español Hablado. Madrid: Gredos. Hummel, Martin 2010. "Reflexiones metodológicas y teóricas sobre el estudio de las formas de tratamiento en el mundo Hispanoablante, a Partir de una Investigación en Santiago de Chile." In Formas y fórmulas de tratamiento en el mundo hispánico, ed. by Martin Hummel, Bettina Kluge, María Eugenia Vázquez Laslop, 103-162. México: El Colegio de México.

Kendall, Martha. 1981. "Toward a Semantic Approach to Terms of Address: A Critique of Deterministic Models in Sociolinguistics." Language in Communication 1 (2-3): 237-254.

Keniston, Hayward. 1937. Syntax. The Syntax of Castilian Prose. Chicago: University Press.

Lambrecht, Knud. 1994. Information Structure and Sentence Form. Topic, Focus and Mental

Representations of Discourse Structures. Cambridge: Cambridge University Press.

Langacker, Ronald W. 1991. Foundations of Cognitive Grammar. Berlin: Mouton de Gruyter. Langacker, Ronald W. 1994. "The Limits of Continuity: Discreteness in Cognitive Semantics." In Continuity in Linguistic Semantics, ed. by Catherine Fuch, and Bernard Victorri, 9-20. Amsterdam: Benjamins.

Langacker, Ronald W. 2009. Investigations in Cognitive Grammar. Berlin: Mouton de Gruyter.

Martiny, Thierry. 1996. "Forms of Address in French and Dutch: A Sociopragmatic Approach." Language Sciences 18 (3-4): 765-775.

Medina López, Javier. 2009. “El tú del presidente. La ruptura del rol social.” Revista Española de Lingüística 39 (1): 77-109.

Medina Morales, Francisco. 2010. "La metodología en los estudios sobre formas y fórmulas de tratamiento en español." In Formas y fórmulas de tratamiento en el mundo hispánico, ed. by Martin Hummel, Bettina Kluge, and María Eugenia Vázquez Laslop, 23-56. México: El Colegio de México.

Miñano López Julia. 2007. Y ahora la gramática, 1. Nivel principiante. Barcelona: Publicaciones y Ediciones de la Universidad de Barcelona.

Morford, J. 1997. "Social Indexicality in French Pronominal Address." Journal of Linguistic Anthropology 7: 3-37.

Mühlhäusler, Peter, and Rom Harré. 1990. Pronouns and People. Massachusetts: Basil Blackwell.

Nowikow, Wiaczeslav. 2010. "Sobre los motivos del empleo de tú y usted. de estudiantes universitarios en Guadalajara (Jalisco, México) desde la perspectiva de los enfoques socio y etológico-lingüísticos." In Formas y fórmulas de tratamiento en el mundo hispánico, ed. by Martin Hummel, Bettina Kluge, and María Eugenia Vázquez Laslop, 795-808. México: El Colegio de México.

Pennycook, Alastair. 1994. “The Politics of Pronouns.” ELTJ 48 (2): 173-178.

Prince, Ellen F. 1981. “Toward a Taxonomy of Given-New Information.” In Radical Pragmatics, ed. by Peter Cole, 223-255. New York: Academic Press.

Rosengren, Paul. 1974. Presencia o Ausencia de los Pronombres Personales Sujetos en Español Moderno. Stockholm: Acta Universitatis Gothoburgensis.

Sacks, Harvey. 1972. “On the Analysability of Stories by Children.” In Directions in Sociolinguistics: The Ethnography of Communication, ed. by John Gumperz, and Dell Hymes, 325-435. New York: Holt, Rinehart and Winston.

Schegloff, Emanuel A. 2007. "A Tutorial on Membership Categorization." Journal of Pragmatics 39: 462-482.

Sánchez López, Cristina. 1993. “Una anomalía del sistema pronominal español.” Dicenda: Cuadernos de Filología Hispánica 11: 259-284.

Serrano, María José. 2001. "La deixis social en los usos pronominales de cortesía en español." Revue de Sémantique et Pragmatique. 9-10: 265-280. 
Serrano, María José. 2006. Gramática del discurso. Madrid: Akal.

Serrano, María José. 2011. “'Otras personas y yo’: Variación socioestilística del pronombre nosotros. en conversaciones espontáneas.” In Variación variable, ed. by María José Serrano, 93-126. Almería: Círculo Rojo/Ministerio de Ciencia e Innovación.

Serrano, María José. 2012. "El sujeto pronominal usted. / ustedes. y su posición. Variación y creación de estilos comunicativos." Spanish in Context 9 (1): 109-131.

Serrano, María José, and Miguel Ángel Aijón Oliva. 2012. "Cuando tú eres yo: La inespecificidad referencial de tú. como recurso de objetivación en el discurso." Nueva Revista de Filología Hispánica 60: 541-563.

Serrano, María José, and Miguel Ángel Aijón Oliva. 2014. “Discourse Objectivization, Social Variation and Style in the Use of Spanish Second-Person tú." Folia Lingüística 48 (1): 225-253.

Silva-Corvalán, Carmen. 2001. Sociolingüística y pragmática del Español. Washington DC: Georgetown University Press.

Silverstein, Michael. 2003. "Indexical Order and the Dialectics of Sociolinguistic Life." Language and Communication 23: 193-229

Spencer-Oatey, Helen. 1996. "Reconsidering Power and Distance." Journal of Pragmatics 26: 1-24.

Stewart, Miranda. 2003. "Pragmatic Weight' and Face: Pronominal Presence and the Case of the Spanish Second Person Singular Pronoun tú." Journal of Pragmatics 35: 191-206.

Stirling, Lesley, and Lenore Manderson. 2011. "About you: Empathy, Objectivity and Authority." Journal of Pragmatics 43: 1681-1502.

Theodoropoulou, I. 2014. Sociolinguistics of Style and Social Class in Contemporary Athens. Amsterdam: Benjamins.

Van Compernolle, Rémi A. 2008. Second-Person Pronoun Use and Address Strategies in On-line Personal Ads from Quebec." Journal of Pragmatics 40: 2062-2070.

Van Compernolle, Rémi A. 2011. Developing a Sociocultural Orientation to Variation in Language." Language \& Communication 31 (1): 86-94.

Watts, Richard, Sachiko, Ide, and Konrad Ehlich. 1992. "Linguistic Politeness and Politic Behaviour: Reconsidering Claims for Universality." In Politeness in Language: Studies in its History, Theory and Practice, by Richard Watts et al., 21-42. Berlin: Mouton de Gruyter.

Wilson, John 1990. Politically Speaking: The Pragmatic Analysis of Political Language. Oxford: Blackwell.

Williams, Lawrence, and Rémi A. van Compernolle. 2009. "Second-person Pronoun Use in French Language Discussion Fora." Journal of French Language Studies 19 (3): 363-380.

Zupnik, Janette 1994. "A Pragmatic Analysis of the Use of Person Deixis in Political Discourse." Journal of Pragmatics 21: 339-383.

\section{Author's address}

María José Serrano

Departamento de Filología Española

Universidad de La Laguna, Tenerife

Campus de Guajara s/n 38071

Spain

mjserran@ull.edu.es 